\title{
Frequency analysis for planned islanding operation in the Danish distribution system -
} Bornholm

Chen, Yu; Xu, Zhao; Østergaard, Jacob

\section{Published in:}

UPEC 2008

Link to article, DOI:

10.1109/UPEC.2008.4651467

Publication date:

2008

Document Version

Publisher's PDF, also known as Version of record

Link back to DTU Orbit

Citation (APA):

Chen, Y., Xu, Z., \& Østergaard, J. (2008). Frequency analysis for planned islanding operation in the Danish distribution system - Bornholm. In UPEC 2008 IEEE. https://doi.org/10.1109/UPEC.2008.4651467

\section{General rights}

Copyright and moral rights for the publications made accessible in the public portal are retained by the authors and/or other copyright owners and it is a condition of accessing publications that users recognise and abide by the legal requirements associated with these rights.

- Users may download and print one copy of any publication from the public portal for the purpose of private study or research.

- You may not further distribute the material or use it for any profit-making activity or commercial gain

- You may freely distribute the URL identifying the publication in the public portal 


\title{
Frequency Analysis for Planned Islanding Operation in the Danish Distribution System - Bornholm
}

\author{
Yu Chen \\ cy@elektro.dtu.dk \\ Zhao Xu \\ zx@elektro.dtu.dk \\ Jacob Østergaard \\ joe@elektro.dtu.dk \\ Centre for Electric Technology, Department of Electrical Engineering \\ Technical University of Denmark, Kgs. Lyngby, Denmark
}

\begin{abstract}
The power system in the Danish island Bornholm is a distribution system with a high penetration of wind generation, which is representative for expected future power systems. During the period from $11^{\text {th }}$ to $14^{\text {th }}$ September 2007, the Distribution System Operator (DSO) Østkraft in Bornholm conducted a planned islanding operation test. To evaluate the test and achieve useful experience for future similar operations in Bornholm or even in other similar systems, the frequency data before, during and after this period, were recorded by Phasor Measurement Units (PMUs), supplied by Centre for Electric Technology (CET), Technical University of Denmark (DTU) Statistical analysis of frequency data has been performed and the results reveal that the frequency quality during the islanding period was significantly decreased, indicating the need for enhancing frequency control of such systems in the future.
\end{abstract}

\section{INTRODUCTION}

As shown in Fig. 1, Bornholm is a Danish island in the Baltic Sea, which is situated in the east of Denmark, the south of Sweden and the north of Poland. According to [1], the electric power system in Bornholm is a distribution network consisting of three voltage levels: $60 \mathrm{kV}, 10 \mathrm{kV}$ and $0.4 \mathrm{kV}$. At $60 \mathrm{kV}$ level, the network has 18 nodes, $2360 / 10 \mathrm{kV}$ transformers with On-Load Tap Changer (OLTC), 22 cables and overhead lines. Besides, there is one $60 \mathrm{kV}$ sea cable with $60 \mathrm{MW}$ capacity [2], connecting the Bornholm system to the Swedish system. This cable makes Bornholm a part of the Nordic power system that covers Sweden, Finland, Norway and Eastern Denmark. The Bornholm system is normally inter-connected with the Nordic system.

The peak load in Bornholm is $63 \mathrm{MW}$ while the minimum load is $13 \mathrm{MW}$ in 2007. The generators include 14 Diesel (Oil) units with a total capacity of $35 \mathrm{MW}, 1$ steam plant

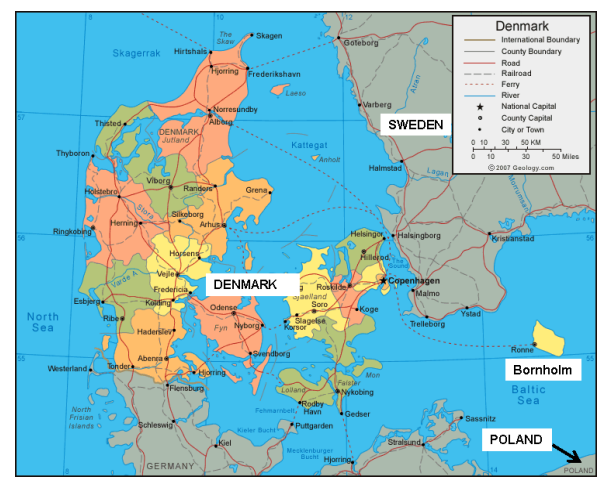

Fig. 1. Location of Bornholm
(BLOK 5) with 25 MW capacity, 1 Combined Heat and Power plant (CHP) (BLOK 6) with 37 MW capacity, 35 Wind Turbines (WTs) with a total capacity of $30 \mathrm{MW}$ and one 2 MW Biogas plant (BLOK 7) [1], [3]. Given so many wind turbines in Bornholm, the maximum penetration level of wind power with respect to minimum load can reach $231 \%$ in 2007 , and $32.4 \%$ of electricity supply was already from wind energy, compared to $19.7 \%$ for the whole Denmark [4]. This percentage will be even higher, in that "A Visionary Danish Energy Policy 2025", published by the Danish government on $19^{\text {th }}$, January 2007 , has highlighted that at least $30 \%$ of total energy consumption in Denmark should be supplied by renewable resources [5]. To fulfill this goal, the new policy expects that $50 \%$ of total electricity demand should be supplied by wind power by 2025 . Since Bornholm already has a high share of electricity supplied by renewable energy, particularly wind power, its system can be a representative of future systems, so as the challenges that have appeared in system operation and control.

From time to time, the sea cable to Sweden was disrupted by the anchor of ships that passed around the island, which forced Bornholm system to run into islanding mode in periods of several weeks. During those periods, frequency control of the system became fairly difficult and the Distribution System Operator (DSO) Øskraft had to shut down most WTs. The experiences of those islanding operations in practice reveal that the existing technology failed to operate such system with high penetration of WTs. In order to achieve clear understanding of the challenge, the system performance during islanding operation periods should be analyzed carefully, which is the main focus of this paper. Such analysis will provide useful insights into the nature of the problem and then facilitate the research and development of new technologies in need.

In this paper, the system performance analysis is based on the data from a planned islanding operation in Bornholm, since it has not been possible to collect all needed data during previous islanding accidents. Those system data, including frequency, voltage, current, power, phase angle, etc., were collected by three measurement systems: the SCADA system for monitoring and operation [6], SonWin system for business transactions [7] and two Phasor Measurement Units (PMUs) [8]. In addition, there is a measurement system for six Vestas WTs [9]. Details of these systems are presented in Table I. 
TABLE I

MEASUREMENT SYSTEMS IN BORNHOLM

\begin{tabular}{|c|c|c|c|}
\hline System & Supplier & $\begin{array}{l}\text { Time } \\
\text { resolution }\end{array}$ & Data items \\
\hline $\begin{array}{l}\text { Settlement } \\
\text { system-SONWIN }\end{array}$ & SONLINC & 15 minutes & $\begin{array}{l}\text { Average Active Power } \\
\text { (MW) and Reactive } \\
\text { Power (Mvar) }\end{array}$ \\
\hline $\begin{array}{l}\text { SCADA system - } \\
\text { Network } \\
\text { Manager for } 60 \\
\mathrm{kV} \text { and } 10 \mathrm{kV} \\
\text { network }\end{array}$ & $\mathrm{ABB}$ & $\begin{array}{l}10 \text { seconds } \\
1 \text { minute } \\
1 \text { hour }\end{array}$ & $\begin{array}{l}\text { Current (A), Voltage } \\
(\mathrm{kV}), \text { Power Factor (Cos } \\
\text { phi), Tap Position, } \\
\text { Frequency (Hz, only in } \\
\text { HASLE station), Active } \\
\text { Power (MW) and } \\
\text { Reactive Power (Mvar) in } \\
\text { sea cable (only in HASLE } \\
\text { station) }\end{array}$ \\
\hline PMU system & $\begin{array}{l}\text { CET, } \\
\text { DTU }\end{array}$ & $20 \mathrm{~ms}$ & $\begin{array}{l}\text { UTC, Voltage (kV), } \\
\text { Current (A), Phase Angles } \\
\text { (degree) of Voltage and } \\
\text { Current, Frequency (Hz), } \\
\text { Change rate of Frequency } \\
(\mathrm{df} / \mathrm{dt})\end{array}$ \\
\hline \multirow{2}{*}{$\begin{array}{l}\text { VestasOnline }{ }^{\circledR} \\
\text { Business SCADA } \\
\text { system for } 6 \text { wind } \\
\text { turbines }\end{array}$} & \multirow{2}{*}{ VESTAS } & instant & $\begin{array}{l}\text { Status, Power, Wind } \\
\text { Speed, Voltage, Current, } \\
\text { Temperatures and Alarms }\end{array}$ \\
\hline & & $\begin{array}{l}10 \text {-minute } \\
\text { average }\end{array}$ & $\begin{array}{l}\text { Mean Values, Standard } \\
\text { Deviations, Minimum and } \\
\text { Maximum Values }\end{array}$ \\
\hline
\end{tabular}

Since frequency control is the challenge in focus and the PMUs have high accuracy and fine time resolution (20ms) [10], we mainly analyzed the PMU frequency data. The measurement of PMUs is synchronous to Universal Time Coordinated system or UTC. (UTC is 2 hours later than Central European Summer Time, or CEST.) The data therefore can accurately reflect the system status at exactly the same moment. Section III explains the PMU frequency data in detail after Section II, which describes the planned islanding operation. In Section VI, relevant analysis results are presented. Finally, Section V draws several conclusions.

\section{The Planned IsLANDing OPERAtion}

From $11^{\text {th }}$ to $14^{\text {th }}$ September 2007, DSO Østkraft conducted a planned islanding operation. The purposes are to test the system's capability to go into islanding operation mode and to accumulate operation experience. Centre for Electric Technology (CET) at Technical University of Denmark (DTU) was invited to participate and the task was to collect all measurement data and perform analysis subsequently.

The whole operation was conducted in three major stages. At the first stage, Bornholm system was operated under the grid-connection mode, where it was synchronized to the Nordic system and participated in Nord Pool, i.e., the Nordic electricity market. The demand was supplied mainly by the sea cable, WTs and BLOK6. Before disconnection, several planned operations have been conducted in sequence.

First, most WTs were shut down. This is because in previous islanding operations, BLOCK 6 was unable to follow up with the fluctuations of wind power if too much was integrated. Second, in order to replace the power supplied by the sea cable, the normally out-of-service BLOK5 was gradually started to produce power. This, together with other generators, limited the power flow in the cable to the least level, preparing for a smooth transition later on.

The second stage includes the disconnection operation and the following islanding operation mode. Once the sea cable was disconnected, Bornholm system was asynchronous to Nordic system and became a separated $60 \mathrm{kV}$ Medium Voltage Microgrid [11]. It did not participate in Nord Pool any more; instead, the electricity was traded in a regulated way at a fixed or contracted price. After around one day, three large WTs with $6 \mathrm{MW}$ capacity in total were started and continued produce power afterwards. At this stage, BLOK5 and BLOK6 supplied the most demand while the three WTs only supplied less than $4 \%$ of the total demand, which was much lower than the level under grid-connection mode.

Bornholm system was synchronized and returned to gridconnection mode by reconnecting the sea cable. Subsequently, the power from BLOK5 was gradually decreased to zero, and the power through the sea cable was increased to the normal level within around one hour after reconnection. Meanwhile, all WTs were in service and Bornholm system can participate in Nord Pool again. This is the last stage.

Those three stages have been summarized in Table II.

\section{FREQUENCY DATA}

\section{A. Extracting Data from PMUs}

The frequency in Bornholm was measured by the PMU BORNH1, which is installed on the low voltage side of the machine transformer of BLOK5. The frequency data from PMU - HVE400, which is installed on the $400 \mathrm{kV}$ high voltage side of a substation in Zealand (within Eastern Denmark), are used for comparison purpose, since they are the frequency of the Nordic system.

Due to a calibration problem of BORNH1, the frequency data are not complete for the whole islanding period, except phase angle data. Nevertheless, the missing frequency data $f$ can be calculated from the phase angle difference $\Delta \theta$ using

$$
f=50 \cdot \frac{2 \pi-\Delta \theta}{2 \pi}
$$

TABLE II

STAGES OF THE ISLANDING OPERATION IN SEPTEMBER, 2007

\begin{tabular}{|l|l|l|}
\hline Stage & Operation & Time (CEST) \\
\hline $\begin{array}{l}\text { Stage } \\
\text { One }\end{array}$ & Nordic Grid-connection & Before 07:25, 11-09 \\
\hline $\begin{array}{l}\text { Stage } \\
\text { Two }\end{array}$ & Disconnection & At 07:25, 11-09 \\
\cline { 2 - 3 } & Islanding operation & From 07:25, 11-09 to 13:00, 14-09 \\
\hline \multirow{2}{*}{$\begin{array}{l}\text { Stage } \\
\text { Three }\end{array}$} & Reconnection & At 13:00, 14-09 \\
\cline { 2 - 3 } & Nordic Grid-connection & After 13:00,14-09 \\
\hline
\end{tabular}


with acceptable approximation. Thus, the frequency data in Bornholm for analysis consist of two parts: one includes the frequency calculated from phase angle; the other is directly from BORNH1. Their availability within the islanding operation period is shown in Fig. 2.

Equation (1) approximates the frequency based on phase angle. To validate such approximation, we compared the calculated frequency data with PMU frequency data in the part with both angle and frequency data. The results showed that approximation by (1) would introduce additional noise into the resultant frequency data. Such noise, due to the difference between interpolation to frequency and interpolation to phase angle, has been analyzed. To smooth out the noise, one 4-sample moving average filter was applied to the data. The selected filtering algorithm can provide satisfactory performance. This will not be analyzed in detail herein, since it is not the focus of this paper. The filter used can be expressed as:

$$
y(n)=\frac{1}{4} x(n)+\frac{1}{4} x(n-1)+\frac{1}{4} x(n-2)+\frac{1}{4} x(n-3)
$$

where $x$ represents the data before being filtered and $y$ is the resultant data.

\section{B. Time Plots of the Frequency Data}

The frequencies in Nordic system and Bornholm during the islanding operation period are shown together in Fig. 3, which corresponds to Fig. 2. Bornholm was disconnected from Sweden at 05:25, Sept. $11^{\text {th }}$ and reconnected back at 11:00, Sept. $14^{\text {th }}, 2007$ UTC.

Compared with the Nordic system, the Bornholm frequency fluctuated much more and several severe high/low frequency spikes were observed. To attain clear pictures of the critical transition process, the $20 \mathrm{~min}$ time plots of frequency around both disconnection and reconnection moments have been

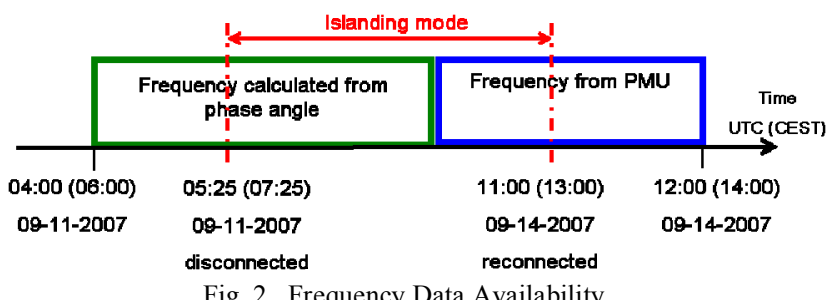

Fig. 2. Frequency Data Availability

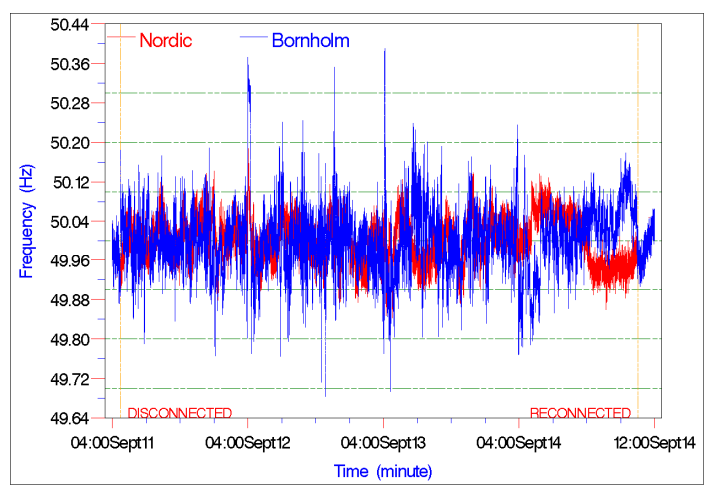

Fig. 3. Plot of Available Frequency Data presented in Fig. 4 and 5, respectively. At the moment of disconnection, there was some power exported to Nordic system since Bornholm frequency jumped from $49.90 \mathrm{~Hz}$ to around $50.18 \mathrm{~Hz}$. Before the reconnection moment in Fig. 5, the power production in Bornholm was adjusted gradually to make the frequency as close to the Nordic system frequency as possible. Once reconnected, the Bornholm system was fully synchronous to the Nordic system, as shown in Fig. 6. However, due to the inrush current at the reconnection moment, the bus voltages in the relatively weak Bornholm system experienced fluctuations, resulting in less than $2 \mathrm{~s}$ fluctuation of Bornholm frequency measured by BORNH1.

As summarized in Table III, 3 complete days' frequency data have been abstracted from the islanding period for comparison studies in section VI.

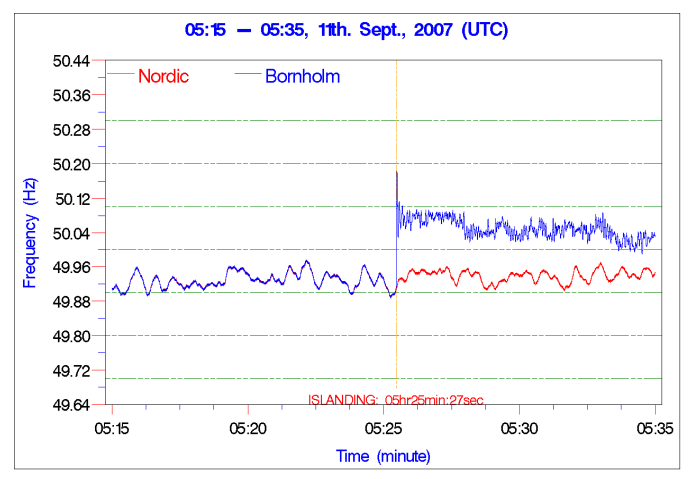

Fig. 4. Disconnection Moment

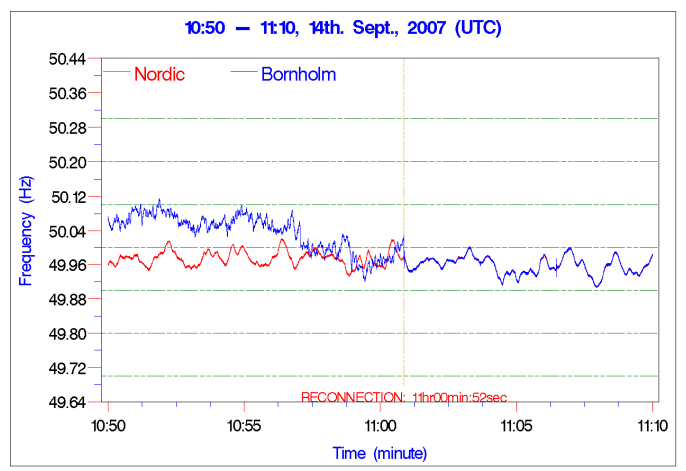

Fig. 5. Reconnection Moment

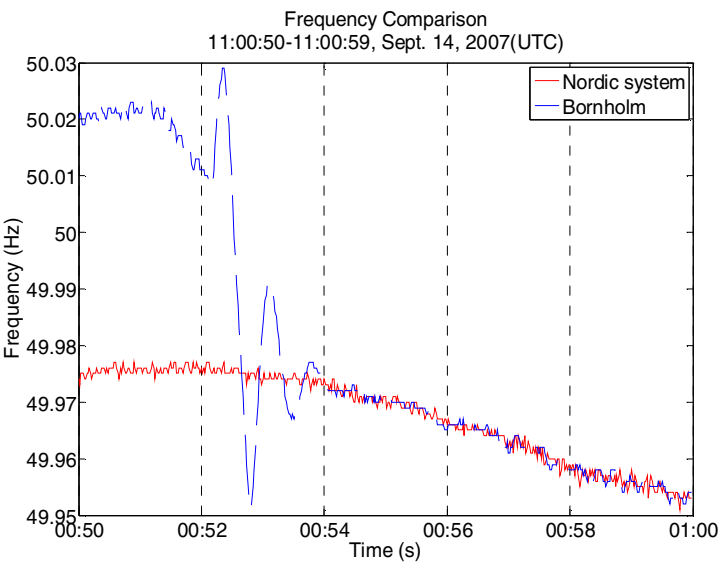

Fig. 6. Zoomed in Reconnection Moment 
TABLE III

DEFINITION OF 3 DAYS

\begin{tabular}{|c|c|c|}
\hline & FROM (UTC) & TO (UTC) \\
\hline Day 1 & $10: 0011-09-2007$ & $10: 0012-09-2007$ \\
\hline Day 2 & $10: 0012-09-2007$ & $10: 0013-09-2007$ \\
\hline Day 3 & $10: 0013-09-2007$ & $10: 0014-09-2007$ \\
\hline
\end{tabular}

IV. STAtistical ANALysis

The analysis has been performed using Statistical Analysis System or SAS software [12]. Maximal, minimal and mean frequency have been calculated and shown in Fig. 7 for each day, based on 4,320,000 data points per day. Besides, the histograms for both Nordic and Bornholm system during 3 days are compared in Fig. 8.

From Fig. 7 and 8, it is obvious that Bornholm had larger maximal and smaller minimal frequency for each day and the frequency deviated much more than its counterpart in Nordic system. This is understandable since the islanded Bornholm system had less inertia and less reserve for frequency control, resulting in higher vulnerability to small disturbances. According to Nordic Grid code 2007 [13], the normal frequency range should be within 49.90-50.10 Hz. During the 3-day's period, the frequency probability within that range in Bornholm is $91.29 \%$, which is lower than $98.77 \%$ in the Nordic system. In addition, the goal for the duration of system operation outside $50 \pm 0.1 \mathrm{~Hz}$ in the Nordic system is suggested to be less than $1200 \mathrm{~min} /$ year, or correspondingly

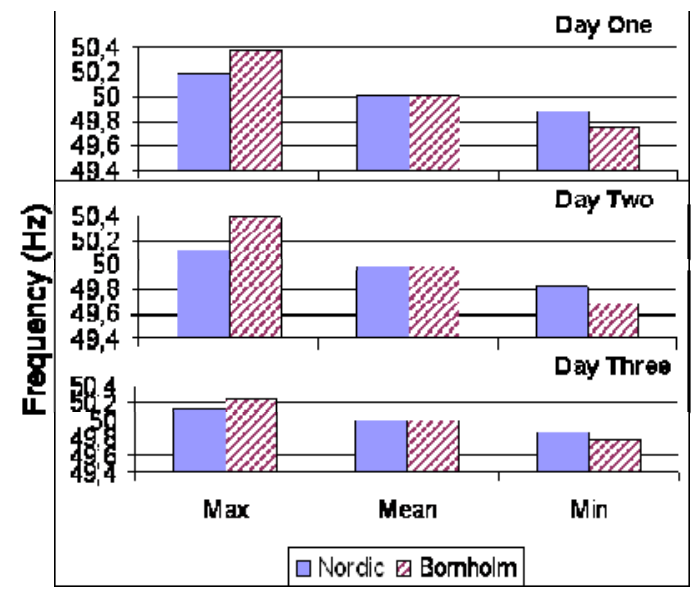

Fig. 7. Max/Mean/Min Value for Three Days

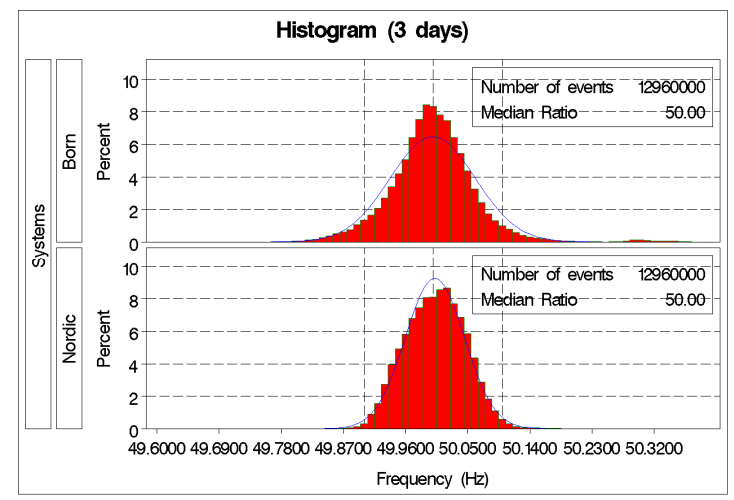

Fig. 8. Frequency Histograms of 3 Days less than $0.228 \%$ in a one year period [14]. It is clear that the frequency quality in Bornholm was considerably decreased in Fig. 9, indicating that the Nordic Grid code can not be well fulfilled.

To further probe the feature of low/high frequency ( $\mathrm{f}<49.90$ $\mathrm{Hz} / \mathrm{f}>50.10 \mathrm{~Hz}$ ) events, we have plotted the durations of such events versus their counts in Fig. 10 and 11. As observed in both figures, Bornholm has more short and long events of both low and high frequency. This reconfirms the findings in previous figures that the frequency control under the islanding mode becomes more challenging due to insufficient inertia and reserve.

In addition, the probabilities of low frequency $(\mathrm{f}<49.90 \mathrm{~Hz})$ have been plotted versus the minute of the hour in Fig. 12 and 13 for Bornholm and Nordic system, respectively. In the authors' previous work [15], strong correlation between time and low frequency probability has been proved due to the hourly market operation, based on a large amount of frequency data. However, the similar pattern could not be observed in Fig. 12 and 13. This is mainly due to insufficient data amounts for Nordic system.

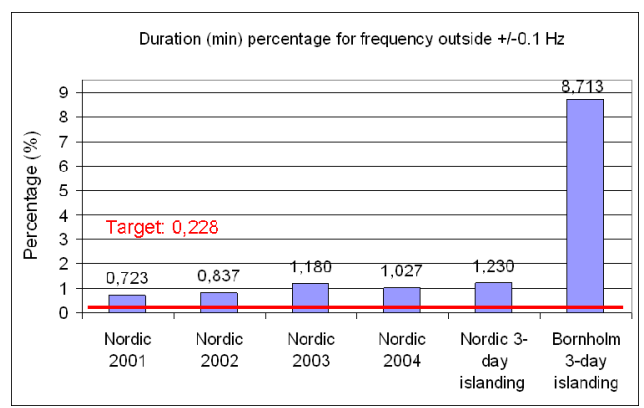

Fig. 9. Duration Percentage Comparison

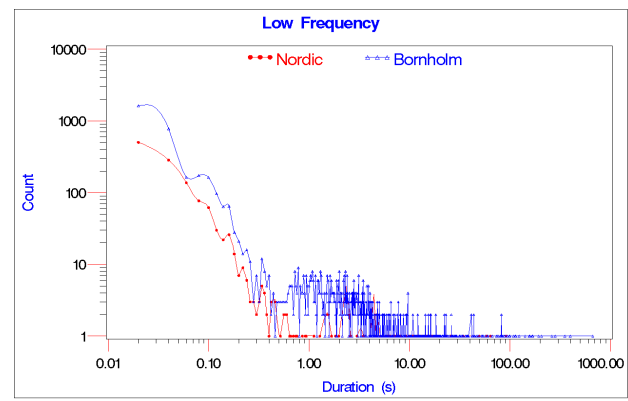

Fig. 10. Low Frequency Duration Analysis

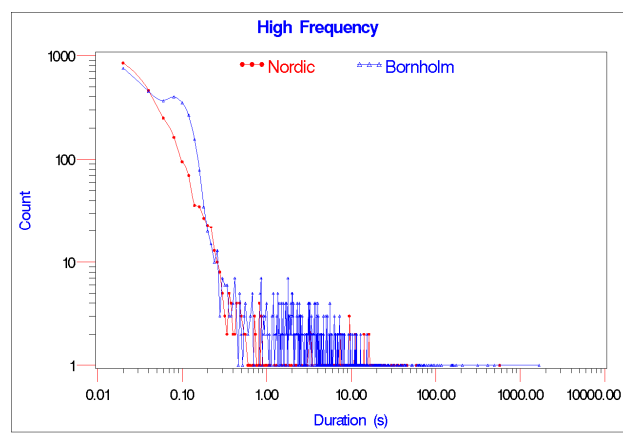

Fig. 11. High Frequency Duration Analysis 


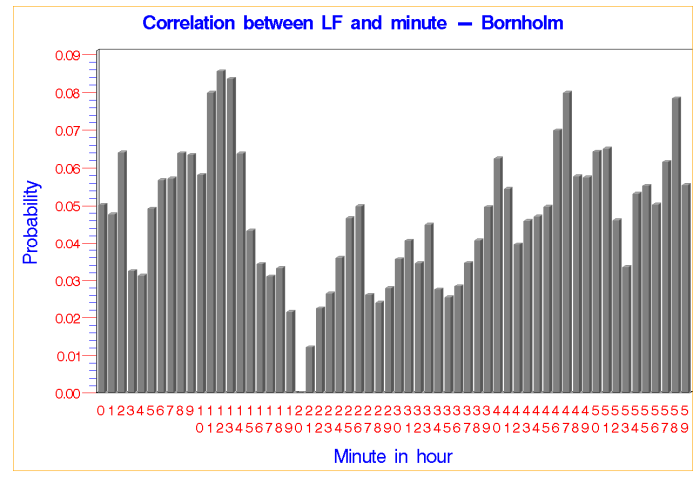

Fig. 12. Correlation for Low Frequency in Bornholm

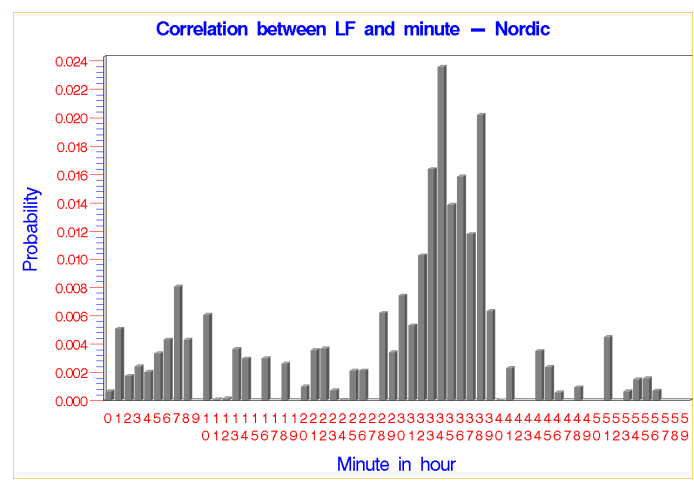

Fig. 13. Correlation for Low Frequency in Nordic System

For Bornholm, this is because it was no longer in the Nord Pool hour-by-hour market after being islanded. However, Fig. 12 and 13 demonstrate again that the Bornholm frequency deviated from the nominal $50 \mathrm{~Hz}$ more than that in the Nordic system.

\section{CONCLUSION}

With the planned islanding operation and the frequency analysis, some conclusions can be drawn:

First, the planned islanding operation in Bornholm is feasible, although well planned preparations are required beforehand, such as the adjustment of power through the sea cable, most WTs should be shut down and BLOK5 needs started. Those experience obtained can be beneficial to future similar operations.

Furthermore, the frequency analysis demonstrates that frequency deteriorated under islanding mode, even though wind power production only accounted for a small share of total electricity supply and the frequency control became difficult due to insufficient inertia and reserve.

Thirdly, the analysis makes it clear that new technologies need to be developed in order to secure the power supply of future systems with high penetration of intermittent Distributed Generations, like Bornholm. The new solutions should enable systems to perform flexible islanding operation during emergency, maintenance or even under the condition of poor power quality. This requires active utilization of all available resources including the electricity demand. As an effective attempt, the Demands as Frequency controlled Reserve (DFR) technology has been investigated with promising results achieved [16]. It has been found that many end-user demands, like refrigerators, freezers and electric heating, can be interrupted for short durations with little effects to customers. Therefore, the DFR is able to support frequency control under various conditions, including the islanding operation. Other technologies that can facilitate flexible islanding operations should also be investigated, including frequency control of WTs, storage devices, etc.

\section{ACKNOWLEDGMENT}

The authors would like to thank Associate Professor Knud Ole Helgesen Pedersen with Siemens - Measurement Systems department and Associate Professor Arne Hejde Nielsen with CET, DTU, for providing detailed information of PMUs. The authors would also like to thank Associate Professor John Eli Nielsen with CET, DTU for contributions about the Bornholm system.

\section{REFERENCES}

[1] J. E. Nielsen, "The Bornholm Power System - An Overview," Centre for Electric Technology, Technical University of Denmark, January 2008, unpublished.

[2] E. James-Smith, and M. Togeby, "Security of Supply of BornholmDemand Side Options for System Reserves," Ea Energy Analyses A/S, September, 2007.

[3] ØSTKRAFT Net A/S. (2007.) Årsrapport 2007. [Online]. Available: http://www.oestkraft.dk/download/oestkraftaarsrapport2007.pdf

[4] The Danish Energy Authority. (2008, Apr.) Windturbines - Introduction and Basic Facts. [Online]. Available: http://www.ens.dk/sw14294.asp

[5] The Danish Energy Authority. (2007, Jun.) Energy Policy Statement 2007.[Online].Available:http://www.ens.dk/graphics/Publikationer/Ene rgipolitik_UK/Energy_policy_Statement_2007/index.htm

[6] ABB Power Technologies. (2003, May.) Network Manager / Distribution.[Online].Available:http://www02.abb.com/global/gad/gad0 2181.nsf/0/b61cdc7de4390c01 c1256e44004da8c0/\$file/Network+Mana ger+Distribution.pdf

[7] Sonlinc, SonWin Product Sheet. [Online]. Available: http://www.sonlinc.com/products/Produktblade/Factsheet_SonWin_Bas ic_ENG_Marts07.pdf

[8] A H. Nielsen et al., "Phasor measurement units in the eastern Danish power system," CIGRE Conference 2006, Paris, France, pp. 1-5.

[9] VESTAS. VestasOnline ${ }^{\circledR}$ Business SCADA System. [Online]. Available: http://www.vestas.com/en/wind-power-solutions/scada

[10] A. H. Nielsen, K. O. H. Pedersen, and O. Samuelsson, "An Experimental GPS-based Measurement Unit," Proceedings of Nordic and Baltic Workshop on Power Systems, Session 1, Tampere, Finland, February, 2002.

[11] N. Hatziargyriou, H. Asano, R. Iravani, and C. Marnay, "Microgrids," IEEE power \& energy magazine, July/August 2007.

[12] Statistical Analysis System Software. Company website: http://www.sas.com/

[13] Nordic Grid Code. (2007.) [Online]. Available: http://www.nordel.org/content/default.asp?pagename= openfile\&DocID $=4948$

[14] B. H. Bakken, and A. Petterteig, "Reserve Requirements and Security of Supply," Capacity Shortage Seminary, Gardermoen, April 26 $6^{\text {th }}$, 2005.

[15] Z. Xu, J. Østergaard, M. Togeby, and F. R. Isleifsson, "Evaluating frequency quality of nordic system using PMU data," Proceedings of the IEEE PES General Meeting 2008, September, 2008, in press.

[16] Z. Xu, M. Togeby, and J. Østergaard, "Demand as Frequency Controlled Reserve - Draft report of the PSO project," March, 2008 